\title{
Model of Learning Development on Program Life Skills Education for Rural Communities
}

\author{
Tri Suminar, Titi Prihatin, and Muhammad Ibnan Syarif
}

\begin{abstract}
This research aims to develop a model of learning in life skills education program valid for rural communities to improve the competitiveness of local seed. The study was conducted by the Research and Development ( $R$ and $D)$. The learning process developed is focused on five components: a) syntactic pattern learning, b) social systems and norms prevailing atmosphere of learning, c) reaction of the management pattern of learning interaction, d) support systems, facilities, materials and learning environment, e) the impact of the companion instructional and learning outcomes. The research location is determined based on the geographical characteristics, the mountainous region of Wonosobo, Kendal coastal areas and industrial centers lying areas Pekalongan. Data were collected through observation, interviews and documentation. The validity of the data by testing credibility include: triangulation, perseverance observation, discussion with colleagues, and then the data is processed by descriptive qualitative. This study resulted in the conceptual design study model based on the four pillars of education life skills education program.
\end{abstract}

Index Terms - Life skills education, models of learning, the four pillars of education.

\section{INTRODUCTION}

The Government of the Republic of Indonesia seeks to increase the availability, affordability and quality of life skills education services for disadvantaged people through life skills education program [1].

Life skills education in national policy perspective is interpreted from the economic aspect, it means life skills education as an investment that is necessary for the survival and accelerated development [2]. In respect of the above statement [3], state investment in education is no less important than the investment in other areas. Reference [4] with the theory of human investment as also explained that a person can increase their incomes through increased education.

The above theory has implications for the implementation

Manuscript received October 19, 2014; revised January 4, 2015. This work is supported by Directorate of Research and Community Service (DP2M) Directorate General of Higher Education of the Republic of Indonesia.

Tri Suminar is with the Departement of Non-Formal Education, Faculty of Sciences Education, Semarang State University (UNNES), Semarang, Indonesia (e-mail: minar_pls@yahoo.co.id).

Titi Prihatin is with the Department of Curriculum and Educational Technology, Faculty of Sciences Education (UNNES), Semarang State University, Semarang, Indonesia (e-mail: titi.prihatin.oce@gmail.com).

Muhammad Ibnan Syarif is with the Department of Fine Arts, Faculty of Language and Art, Semarang State University (UNNES), Semarang, Indonesia (e-mail: ibnan_syarif@yahoo.co.id). of life skills education should provide quality education services. But the findings [5] life skills education in rural vocational program, the learning process only limited practical vocational skills. Learning the practice has not been based on the study of relevant theory so that learners can take decisions in problem solving. Representative model of learning in life skills education should be on skill learning framework that is more accommodating to the development and the demands of the times in the era of globalization [6].

Another basic requirement of effective learning model is a condition characteristic of learners in rural communities still simple cultural patterns, social interactions are colored primary relationships and knowledgeable low. As explained in the theory learned Vygosky that social interaction experience cultural factors influence the development of cognitive maturity influential person who is also on the ability of the learning process.

Some basic psychological theories of learning into the development of learning model is: a) the theory of andragogy by Knowles; b) progressive theory by Dewey; d) the humanistic theory by C.L Rogers; e) learning theory as empowerment by [7] who directs the non-formal education programs should focus on community participation.

The purpose of this study is to describe the model factual, analytical model development needs and prepare design study model on life skills education program valid for improving competitiveness of rural communities.

The results of theoretical research is useful as a learning needs assessment model development education and practical life skills to improve the quality of life skills education services for people in rural areas.

\section{METHODS}

This study was designed to approach the Research and Development (R \& D), which is followed by the development of research and dissemination of a model through the process cycle of action, reflection, evaluation, replication, and systematic innovation [8]. At this stage of research using qualitative methods to explore the factual and analytical models model development needs. Phase conceptual model validation using quantitative methods. Subjects were educators life skills education program in rural Central Java province, location studies were selected by purposive sampling, based on the category of the mountains (Wonosobo), beach (Kendal) and industry (Pekalongan).

The focus of research is learning model elements which include: a) syntax, b) social system, c) principles of reaction, d) support system, and (e) instructional and nurturant effects [9]. Data collection techniques using non-participant 
observation, interviews and documentation. The research instrument used observation sheets focused and structured interview guide [10]. The validity of the data with the test of credibility, transferability test, and test confirmability between the results with the research process. Data analysis was conducted qualitative research with interactive techniques, [11]. Validation of conceptual models with Delphi [12].

\section{RESULTS AND DISCUSSION}

\section{A. Factual Learning Model}

Learning implemented based on the needs of learners and the local potential. Educator understanding of the purpose of learning is still limited vocational skills training. Therefore, the mastery of the subject matter of science insights vocational skills and entrepreneurship education has not been adequate. Educators managing adult learning has not been based on the principles of adult learning well.

Model factual learning life skills education as follows.

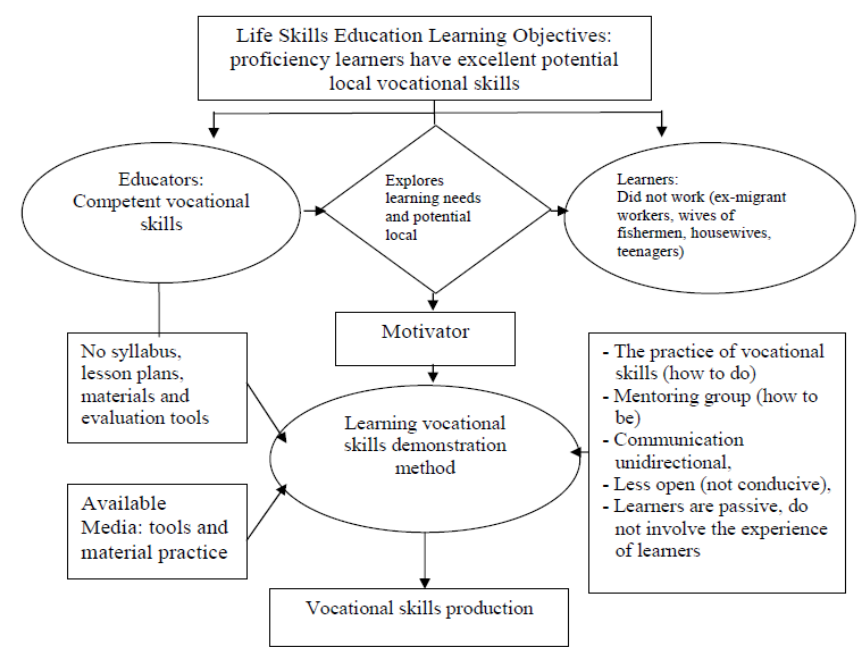

Fig. 1. Model factual learning life skills education program in rural communities.

Based on Fig. 1 above can be explained that the purpose of life skills education program is to equip students with expertise of featured based local vocational skills. Educators were recruited from practitioners who are experts in that skill. Students were recruited from the community who are unemployed adult. Planning learning by educators conducted by assessing local needs and potential learning. Learning begins with the educator's role as a motivator. The process of learning to apply the method practical demonstration of skills, but communication is not yet supported interactive and adequate infrastructure. Learners can produce technical skill proficiency.

\section{B. Discussion}

\section{1) Factual learning model}

The purpose of life skills education program has been formulated in accordance with the theory of andragogy that prioritize the interests of the target adult learners through the learning needs assessment and carrying capacity of the environment as a source of learning [13]. These findings can be analyzed from the theory of progressive learning [14] that the interests of learners learning can increase the active participation of learners.

Syntactic learning life skills education program for rural communities both held in the mountains, the beach or in the industrial centers managed educators focused on the practice of vocational skills that are practical, contextual, meaning in life, namely to work. However, this study has not been fully implemented andragogi, because students do not participate actively during the learning process. This condition can be interpreted from the aspect of learning management that the learning process is influenced by external inputs learners [15]. The findings suggest educators have not leverage the potential of the learning experience of students as learning resources, as well as efforts to increase motivation to learn. Educators have a role as a facilitator in the psychomotor and affective domain as a motivator in the well. But do not act as informator regarding basic knowledge (how to know) for reasoning in solving problems (cognitive) as the scope of the life skills education [16], [17].

Social systems during the learning process has still showed predominantly unidirectional communication educators. Conducive learning environment and there should be an effective interactive communication between learners with educators, is open, so that learning can be fun. As research findings [18], developed a learning cooperative learning peers (peer tutoring) can improve learning outcomes.

Learning life skills education in the village less supported learning facilities and infrastructure facilities (classrooms), teaching materials, equipment and materials for adequate practice, so that the quality of service learning process is still not good. Described [19], lack of teaching materials and learning tools affect the ability of learners in achieving learning outcomes, particularly for cognitive aspects.

The model has not been done factual and learning outcomes assessment process systematically. Though valid assessment becomes a very important part in learning component [15]. The impact of learning is the psychomotor domain of competence, limited to how to do, but have not yet become an expert (learning to be) and yet helpless in a group together to manage the entrepreneur [20]-[23].

\section{2) Conceptual model development needs-based learning four pillars of education}

Based on the model of the factual and development needs of the above models can be structured conceptual model as follows.

Thus the learning paradigm of life skills educators need to be changed understood that the scope of the study of life skills education is not the only aspect of specific skills (vocational) to work alone, the scope of life skills education includes three other dimensions, namely: cognitive skills (critical thinking, taking decision, accept the risk), social skills (communication skills, negotiation, collaboration, empathy) and personal skills (managing emotions, self and self control [24]-[26].

Based on Fig. 2 above can be explained competencies are life skills education graduates have the basic knowledge related insight skill work (services / production) are occupied (cognitive), tough tenacious personality, socialize with confidence (effective aspect), can solve the problem during 
work or manage entrepreneurial (psychomotor aspects) to improve the quality of life.

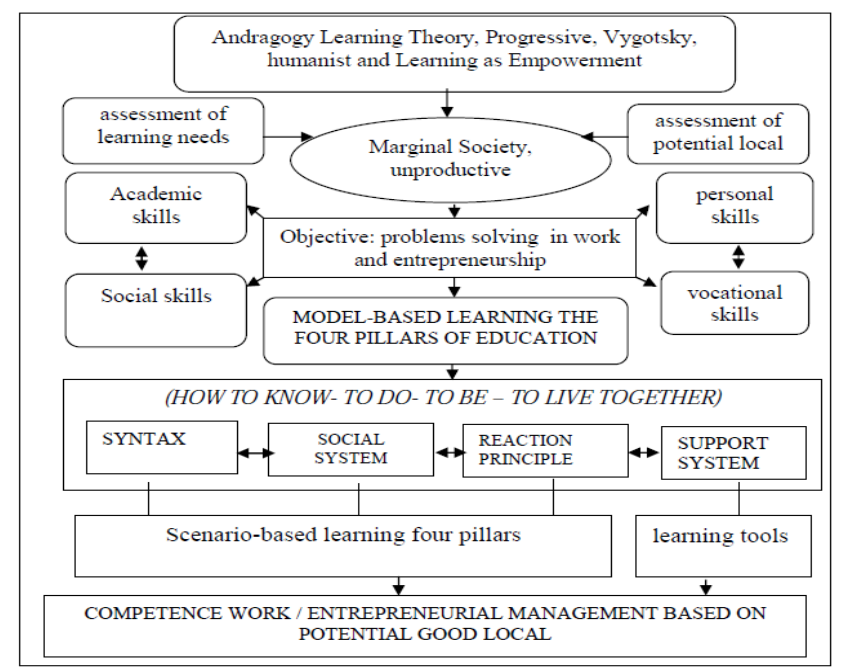

Fig. 2. Conceptual model of learning based four pillars of education life skills education program.

The purpose of learning the life skills education program for rural communities are solving problems in work and entrepreneurship. To achieve the objectives of this study requires villagers have complex learning skills. Therefore, the learning model is based on four pillars representative education based on some theory of learning. Progressive theory, learning is based on the characteristics of individual needs, humanistic theory, increase the active participation of learners. Sociocultural theory, the development of thinking influenced the culture of social interaction. Theory of Andragogy, adults assumed to be independent, ready to learn with high learning motivation to solve problems of practical life.

Application of learning models based on adult learning methods (andragogy) and solving the problem with the scenario as follows: syntactic educators as a motivator, informator, and facilitator, learn to know the concept of entrepreneurship, think creatively finding business opportunities, develop a business plan that is realistic as needed market, becoming an expert in managing entrepreneur with various problems and learn to develop entrepreneurship through networking or living together with the wider community. Learning implemented in an interactive social system, participatory and supported infrastructure for effective learning, involving the experiences of learners and the environment as a learning resource. Directly impact student learning skillful planning and managing entrepreneurial. Indirect impacts learners have an entrepreneurial spirit.

Validation of the expert to the conceptual model through the Delphi technique was measured by a questionnaire scale 1-4 based indicators: average of 3.175 consistency substantive content (good); 3.453 average linkage element (good); the use of a mean of 3.15 (good) and the physical appearance of products 2,975 (enough).

\section{CONCLUSION}

Educators understanding about the scope and purpose of life skills education is still limited to only vocational skills, so that planning and learning process has not been effective to equip learners skills to work or manage entrepreneurship.

Life skills education programs contain multiple life skills, thus demanding the ability of educators to develop instructional design constructed based on the four pillars of education namely how to know, how to do, how to be, and how to live together. the learning model is based on four pillars refers to the theory of andragogy, humanist, progressive, vygotsky and empowerment.

Design of the four pillars of learning models with demonstrations and problem solving methods can achieve some skill, namely: a). cognitive academic skills, learn to know the pillars, b). personal skills and social skills affective, pillar learn to be, and c). vocational skills to work psychomotor skills, pillar learn to do and to live together.

\section{REFERENCES}

[1] M. Nuh, "Strategi dan arah kebijakan pembangunan pendidikan dan kebudayaan tahun 2010-2014," Rencana Strategis Kementerian Pendidikan dan Kebudayaan, pp. 47-82, 2013.

[2] A. Salim et al., Pendidikan Sebagai Investasi Sumber Daya Manusia Dalam Peradaban Bangsa, Badan Penelitian dan Pengembangan Departemen Pendidikan Nasional, 2007, pp. 10-14.

[3] E. Cohn, The Economics of Education: An Introduction, Massachussetts: Ballinger Publishing Company, 1979, pp. 128-134.

[4] T. W. Schultz, "Invesment in human capital," The American Economics Review, no. 51, March 1961.

[5] T. Suminar, "Pengembangan model manajemen pelatihan program pendidikan kecakapan hidup berbasis kewirausahaan keunggulan lokal pada rintisan desa vokasi kabupaten semarang," PhD Dissertation, Graduate Program, State University of Semarang (UNNES), Semarang, 2012

[6] Zamroni, Pendidikan dan Demokrasi dalam Transisi (Prakondisi Menuju Era Globalisasi), Jakarta: PSAP Muhammadiyah, 2007.

[7] S. Kindervatter, Lifelong Education Centers Youth Development Training Program Assesment, Bangkok: Adult Education Division, Ministry of Education, 1979.

[8] W. R. Borg and M. D. Gall, Educational Research: An Introduction, New York: Longman, 1983, pp. 47-72.

[9] B. Joyce, M. Weil, and E. Calhoun, Models of Teaching, Translation Achmad Fawaid and Ateilla Mirza, Yogyakarta: Pustaka Pelajar, 2009, pp. 97-115.

[10] R. C. Bogdan and S. K. Biklen, Qualitative Research for Education: An Introduction to Theory and Methods, Boston: Allyn and Bacon, Inc., 1982, pp. 70-93.

[11] M. B. Miles and A. M. Huberman, Qualitative Data Analysis, Translation Tjetjep Rohendi Rohidi, Jakarta: Universitas Indonesia Press, 1992, ch. I, pp. 1-25.

[12] Y. Jakaria, "Uji coba model (Validasi)," in Proc. Training Research and Development Research and Development, organized by Pusat Penelitian Kebijakan dan Inovasi Pendidikan. Badan Penelitian dan Pengembangan, Depdiknas, Jakarta, 2009, pp. 4-6.

[13] M. S. Knowles, E. F. Holton III, and R. A. Swanson, The Adult Learner: The Definitive Classic in Adult Education and Human Resource Development, 6th ed, United States of America Elsevier Inc., ch. 5, pp. 73-114.

[14] J. Dewey, Democracy and Education An Introduction to the Philosophy of Education, New York: The Free Press A Division of Macmillan Publishing Co. Inc., 1966, ch. 7, pp. 81-99.

[15] D. Sudjana, Sistem dan Manajemen Pelatihan: Teori dan Aplikasi, Bandung, Falah Production, pp. 7-9.

[16] P. H. Slamet, "Pendidikan kecakapan hidup: Konsep dasar," Jurnal Pendidikan dan Kebudayaan Badan Penelitian dan Pengembangan, Departemen Pendidikan Nasional, no. 37, pp. 541-561, 2002.

[17] J. Delors, Learning: The Treasure within, Report to UNESCO of the International Commission on Education for the Twenty-first Century: Printed by Presses Universitaires de France, Vendôme, 1996, part two, pp. 85-97.

[18] I. W. Redhana, "Pengaruh model pembelajaran seminar socrates terhadap hasil belajar siswa," Dalam Cakrawala Pendidikan, vol XXXIII, no. 1, pp. 27-38, 2014. 
[19] Z. Arif, Andragogi, Bandung: Angkasa Bandung, 2012.

[20] S. Kindervatter, Non Formal Education as an Empowering Process, University of Massachusetts, 1979.

[21] M. L. Kourilsky and W. B. Walstad, "Entrepreneurship and female youth: knowledge, attitude, gender differences, and educational practices," Journal of Business Venturing, vol. 13, no. 1, pp. 77-88, 1998.

[22] N. Indarti and D. Rokhima, "Intensi kewirausahaan mahasiswa: Studi perbandingan antara Indonesia, Jepang dan Norwegia," Jurnal Ekonomika dan Bisnis Indonesia, vol. 23, no. 4, 2008.

[23] H. Widyastono, Pengembangan Pendidikan Kewirausahaan, Badan Penelitian dan Pengembangan Pusat Kurikulum, Kementerian Pendidikan Nasional RI, 2010.

[24] V. M. Pinotti, "Life skills approach to child and adolescent healthy human development," Health and Human Development Programs (HHD), Washington DC, 2001, p. 6.

[25] Team Broad-Based Education, Pendidikan Berorientasi Kecakapan Hidup (Life Skill) Melalui Pendekatan Broad-Based Education (BBE), Departemen Pendidikan Nasional, 2002, pp. 5-12.

[26] F. Taute, "Life skills training as part of employee assistance programs in South Africa," The International Journal of the Humanities, vol. 6 no. 4, pp. 41-48, 2005.

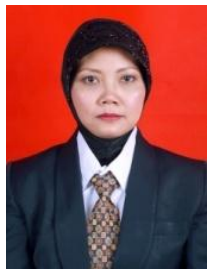

Tri Suminar was born in Tulungagung, on May 26, 1967. She received S3 education management studies program graduated in 2012 and doctorate in the field of management education (Dr).

She worked as a lecturer in the non-formal education study program of the Faculty of Science Education and State University of Semarang (UNNES), Indonesia, since 1995, and management education program studies (S2) since 2012. She now gets additional duties as the secretary of the Department Non-Formal Education.
She is a member of IKAPNFI (Ikatan Akademisi Pendidikan Nonformal Informal). She published the paper entitled "Analysis of quality of higher education services (A case study in the study program faculty of education, State University of Semarang-Indonesia," in Journal EDUKASI, in 2014.

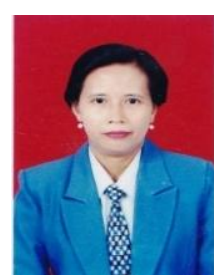

Titi Prihatin was born in Banyumas, on February 12 1963. She received S3 field of management education and obtained his doctorate in 2009.

She worked as a a lecturer in the curriculum and educational technology (S1) program study of the Faculty of Science Education, since 1999 and management education program studies ( $\mathrm{S} 2$ and $\mathrm{S} 3$ ) in the State University of Semarang, since 2009 to now. She has been a consultant primary and secondary education in the education department at the provincial level.

She published one paper entitled "Effect of pensiasatan interactive learning strategies RFM for obtaining student in subjects," in Journal of Educational Research Semarang State University, in 2009.

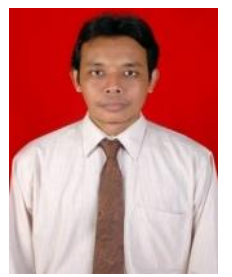

Ibnan Muhammad Sharif was born in Tulungagung, on September 22, 1967. He worked as a lecturer in Art Education, Language and Art Faculty UNNES, since 1992. He was still completing his doctoral dissertation at the University of Gajah Mada (UGM) in Yogyakarta.

$\mathrm{He}$ has a national strategic research grant entitled "Improving productivity and marketing crafts water hyacinth in rawapening for measuring empowerment zone small industry in semarang district". He also wrote a book in 2009 titled The Art of Craft and Local Wisdom in Tracks Space and Time. 